\title{
Tectonic Escape Mechanism in the Crustal Evolution of Eastern Anatolian Region (Turkey)
}

\author{
Ömer Elitok ${ }^{1}$ and M. Nuri Dolmaz ${ }^{2}$ \\ 'Süleyman Demirel University, Department of Geological Engineering, Isparta, \\ 2Süleyman Demirel University, Department of Geophysical Engineering, Isparta \\ Turkey
}

\section{Introduction}

The Neotectonic evolution of Turkey has been dominated by the collision of the African and Arabian plates with the Eurasian plate along Hellenic arc to the west and the Bitlis-Zagros suture zone to the east. The Eastern Anatolian Contractional Province (EACP) including the Eastern Anatolian High Plateau (EAHP) and the Bitlis-Pötürge Thrust Zone (BPTZ) consists of an amalgamation of fragments of oceanic and continental crusts that squezzed and shortened between the Arabian and Eurasian plates. This collisional and contractional zone is being accompanied by the tectonic escape of most of the Anatolian plate to the west by major strike-slip faulting on the right-lateral North Anatolian Transform Fault Zone (NATFZ) and left-lateral East Anatolian Transform Fault Zone (EATFZ) which meet at Karlova forming an east-pointing cusp (Figure 1). The present-day crust in the area between the easternmost part of the Anatolian plate and the Arabian Foreland gets thinner from north (ca $44 \mathrm{~km}$ ) to south (ca $36 \mathrm{~km}$ ) relative to its eastern (EAHP) and western sides (central Anatolian region). The contraction and thickening of the crust to ca $50-52 \mathrm{~km}$ (Dewey et al., 1986; Pearce et al., 1990) in the collisional zone has been accompanied by the tectonic escape of most of the Anatolian crustal block (Anatolian wedge in Dewey et al., 1986; Anatolian platelet in Koçyiğit et al., 2001; Anatolian plate in Y1lmaz et al., 1998; Anatolian block in Lyberis et al., 1992) to the west-southwest towards the Aegean-Cyprean arc system by major strike-slip faulting on the right-lateral North Anatolian Transform Fault Zone (NATFZ) and left-lateral East Anatolian Transform Fault Zone (EATFZ) (Dewey et al., 1986; Şengör, 1979; Şengör and Yılmaz, 1981 and references therein; Şengör et al., 1985; Dilek and Moores, 1990; Tatar et al., 1996; Hubert-Ferrari et al., 2003; Allen et al., 2004; Barazangi et al., 2006) at a slip rate of $24 \pm 1$ and $9 \pm 1 \mathrm{~mm} / \mathrm{yr}$, respectively (McClusky et al., 2000).

Major tectonic structures such as the Aegean-Cyprean arc system, NATFZ, EATFZ, and Dead Sea Fault Zone (DSFZ) have been played a key role on the neotectonic evolution of the eastern Mediterranean region especially in Late Cenozoic. The westward escape of the Anatolian plate has been accompanied by counterclockwise rotation as well as lateral translation deduced from GPS and paleomagnetic data (Tatar et al., 1996; Reilinger et al., 1997; Platzman et al., 1998; Gürer and Gürer, 1999; McClusky et al., 2000; Özçep and Orbay, 2000; Bozkurt, 2001; Büyüksaraç, 2007). Therefore, the timing of collision-induced westward extrusion of the Anatolian plate has been widely accepted as the commencement of the Neotectonic history of Turkey (Şengör and Yılmaz, 1981; Koçyiğit et al., 2001). Koçyiğit et al. 
(2001) investigated the eastern Anatolian compressional tectonic regime in two main stages: the compressional-contractional and compressional-extensional tectonic regimes corresponding to the pre-tectonic escape period and the syn-tectonic escape period, respectively. However, the driving force causing the westward escape of the Anatolian plate is still under debate, e.g. orogenic collapse or gravity spreading following orogenic crustal shortening and thickening within the Anatolian plate (Seyitoğlu and Scott, 1996; Gautier et al., 1999; Dhont et al., 2006), mantle flow driven lithospheric extrusion (Faccenna et al., 2006; Çoban, 2007).

Eastern Anatolia is dissected into three main lithospheric portions (the Eastern Anatolian High Plateau-EAHP, the Anatolian block, and the Arabian Foreland) by the major tectonic structures (Bitlis-Pötürge Suture Zone, NATFZ and EATFZ). The crust in the easternmost part of the Anatolian plate bounded by the NATFZ and the EATFZ, which corresponds to inner east Anatolia in Büyüksaraç (2007), mainly gets thinner from north (ca $43-44 \mathrm{~km}$ ) to south (ca $36-37 \mathrm{~km}$ ) relative to its eastern (EAHP) and western sides (central Anatolian region) (Figure 2), as proposed by Gök et al. (2007) for the east-southeast Anatolia. On the other hand, this thinner crustal terrain is characterized by very low Pn velocities $(<7.8$ $\mathrm{km} / \mathrm{s}$ ) and high $\mathrm{Sn}$ attenuation which indicate existence of partially molten to eroded mantle lid or occurrence of asthenospheric mantle beneath the crust (Al-Lazki et al., 2003; Gök et al., 2003). This chapter is based on mainly the study of Elitok and Dolmaz (2008) who investigated the geodynamic evolution of crustal thinning in the area between the easternmost part of the Anatolian plate and the Arabian Foreland using the geological and geophysical data. They outlined Curie Point Depth (CPD) map of an area including the eastern Anatolia and the Arabian Foreland, and redrawn the crustal thickness map of the same area on the basis of the estimations of Gök et al. (2007) which are based on receiver functions from recordings of 29 broadband seismological stations.

\section{Geological setting}

On the basis of the nature of underlying basement, the eastern Anatolian contractional zone can be separated into four main crustal terrains: from north to south i) the Pontide Belt, ii) the Eastern Anatolian Accretionary Complex (EAAC), iii) the Bitlis-Pötürge Thrust Zone (BPTZ), and iv) the Arabian Foreland. Most of the eastern Anatolian region and Arabian Foreland are covered by compositionally different and young volcanic units that erupted during the Neogene and Quaternary times (Yazgan, 1981; Pearce et al., 1990; Y1lmaz et al., 1998; Keskin, 2003; Keskin et al., 2006).

The Arabian Foreland in the southeastern Turkey is made up of an almost continuous stratigraphic sequence of mainly shelf sediments in Early Paleozoic to Miocene age resting on a Precambrian basement (Hall, 1976; Yazgan, 1981 and references therein; Pearce et al., 1990; Yılmaz, 1993; Yiğitbaş et al., 1993; Yiğitbaş and Y1lmaz, 1996 and references therein). The foreland volcanism is dominated by basaltic shield and fissure eruptions of transitional tholeiitic-alkaline composition (Pearce et al., 1990). Karacadağ volcano, a low shield volcano situated on the Arabian Foreland, erupted since the Pliocene along a N-S trending set of fissures and craters, spatially associated with the nearby Akçakale graben (Figure 1) (Şengör and Yılmaz, 1981; Şengör et al., 1985 and references therein; Pearce et al., 1990). Pearce et al. (1990) interpreted that small degrees of streching might have caused melting of metasomatized lithosphere by perturbation of the geotherm by heat from upwelling of hot asthenosphere. They also explained that Akçakale graben, a small rift structure with N-S normal faults and located to the SW of Karacadağ, is another indicator of E-W extension, 
although this rift appears to act, at least in part, as a transfer structure between some of the outer thrust of the Arabian Foreland sedimentary sequence.

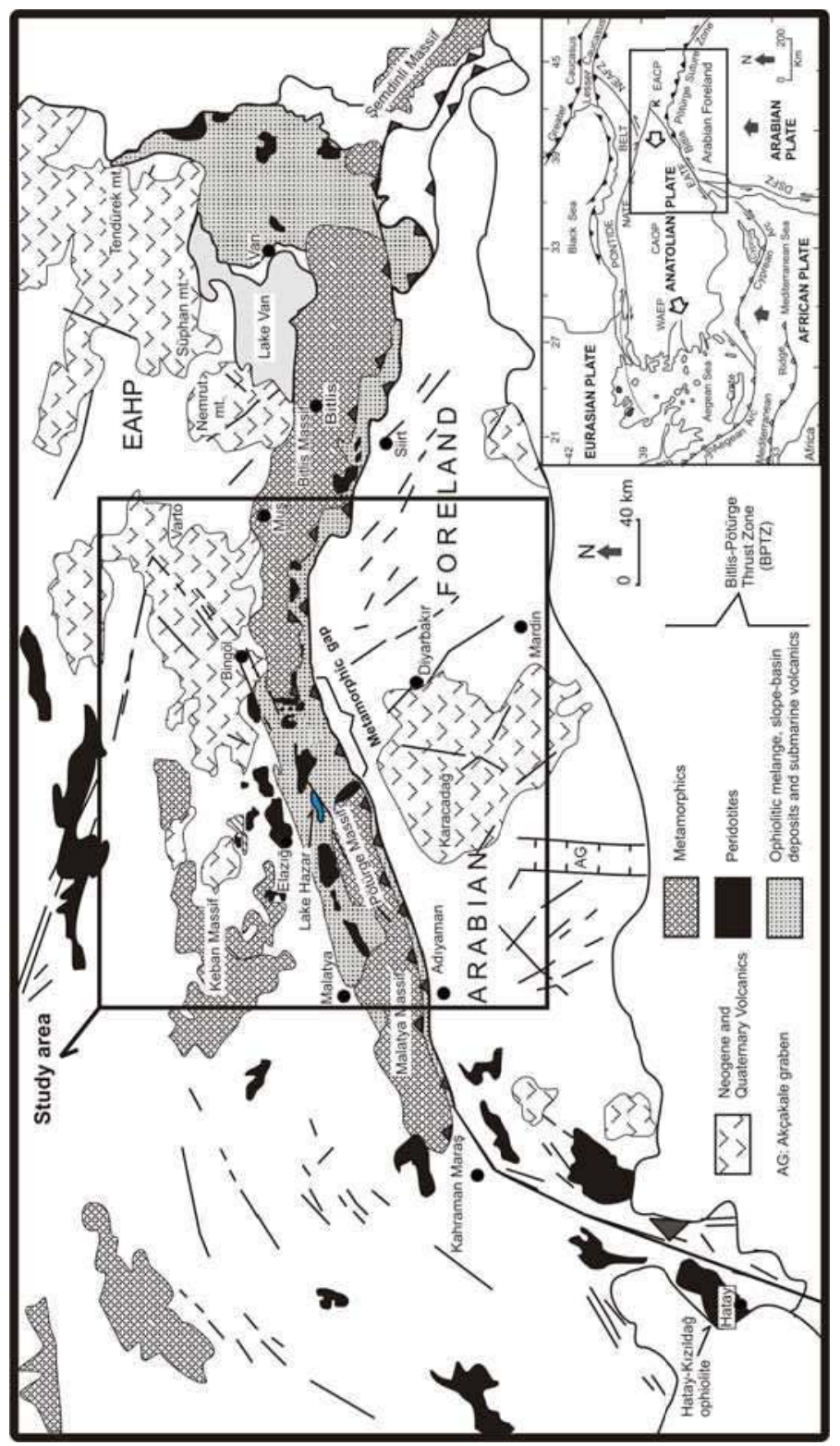

Fig. 1. Simplified geological map of the eastern Anatolian region (from Elitok and Dolmaz, 2008) and the inset location map from Bozkurt (2001), EACP: Eastern Anatolian Contractional Province, EAHP: Eastern Anatolian High Plateau, CAOP: Central Anatolian Ova Province, WAEP: Western Anatolian Extensional Province 
The autochthonous Arabian Foreland is tectonically overlain in the north generally by a nappe package consisting of metamorphic massifs at the top and imbricated ophiolitic rock associations laying below the massifs (Hall, 1976; Yazgan, 1981; Yılmaz, 1993; Yiğitbaş et al., 1993; Yılmaz and Yıldırım, 1996; Yiğitbaş and Yılmaz, 1996). Yılmaz (1993) separated the nappe successions running along the BPTZ into two main groups: i) the nappe zone consisting of two nappe stacks (the upper nappe represented mainly by Bitlis and Pötürge metamorphics; the lower nappe is characterized by the slices of polyphase metamorphic ophiolitic assemblage and the Maden Group), ii) the imbricated zone sandwiched between the Arabian Platform and the nappe zone. In this study we used "the Bitlis-Pötürge Thrust Zone-BPTZ" for the nappe successions including both the nappe zone and the imbrication zone of Yilmaz (1993). In the BPTZ, the metamorphic massifs display an arc-shaped geometry in parallel to Arabian promontory (Figure 1). The Bitlis and Pötürge metamorphic massifs form the highest tectonic units of the Southeast Anatolian orogenic belt (Yiğitbaş and Yilmaz, 1996). However, there is no direct link through a gateway between these metamorphic massifs. This gateway covered by accretionary materials and Tertiary sediments is termed "metamorphic gap" in this study (Figure 1). Consistently, Hall (1976) interpreted that the Bitlis Massif is thrust southward over the ophiolite-flysch complex, whereas in the east and west they are structurally below the same complex. Presumably, the Bitlis and Pötürge massifs might have been dismembered during the indentation of the Arabian plate to the Eurasian plate since the Miocene time. In the metamorphic gap area, even if the metamorphic rocks take place within the accretionary materials and Tertiary sediments, most likely they might be the blocks broken off from the pre-collisional unique Bitlis-Pötürge metamorphic body. The Keban metamorphic rocks and Upper Triassic-Upper Cretaceous platform carbonates of Munzur Mountains are located to the north of the Pötürge Massif.

\section{Crustal structure}

Based on the Eastern Turkey Seismic Experiment (ETSE) project (Sandvol et al., 2003), crustal thickness of east Turkey has been estimated by Zor et al. (2003) and Gök et al. (2007) using receiver functions obtained from teleseismic recordings of 29 broadband seismological stations. Zor et al. (2003) and Şengör et al. (2003) also contoured the crustal thickness of east Anatolia. Elitok and Dolmaz (2008) produced the crustal thickness map of the eastern Anatolian region contouring the moho depth estimates from Figure 7 in Gök et al. (2007) using the standard gridding routine (Figure 2). In the map, the crustal thickness in the easternmost part of the Anatolian plate gets thinner from the NAFZ in the north (ca $44 \mathrm{~km}$ ) to the Arabian Foreland in the south (ca $36 \mathrm{~km}$ ) through the metamorphic gap between the Bitlis Massif and the Pötürge Massif relative to its eastern (EAHP) and western sides (central Anatolian region) (Figure 2). However, the thickness of the crust reaches to ca $45-46 \mathrm{~km}$ in the north of the Bitlis Massif and the Pötürge Massif. The crust sharply thickens in a short interval from 40 to $46 \mathrm{~km}$ in the northern side of the Bitlis Massif (Figure 2). Gök et al. (2007) estimated the average crustal thickness as $36 \mathrm{~km}$ in the northern margin of the Arabian Plate, $44 \mathrm{~km}$ in the Anatolian Block and $48 \mathrm{~km}$ in the Anatolian Plateau. Although Pn velocities are high in the south of the Bitlis Massif implying a stable mantle lid region beneath the northernmost part of the Arabian plate, it sharply stops along the Bitlis Suture Zone (Al-Lazki et al., 2003). 


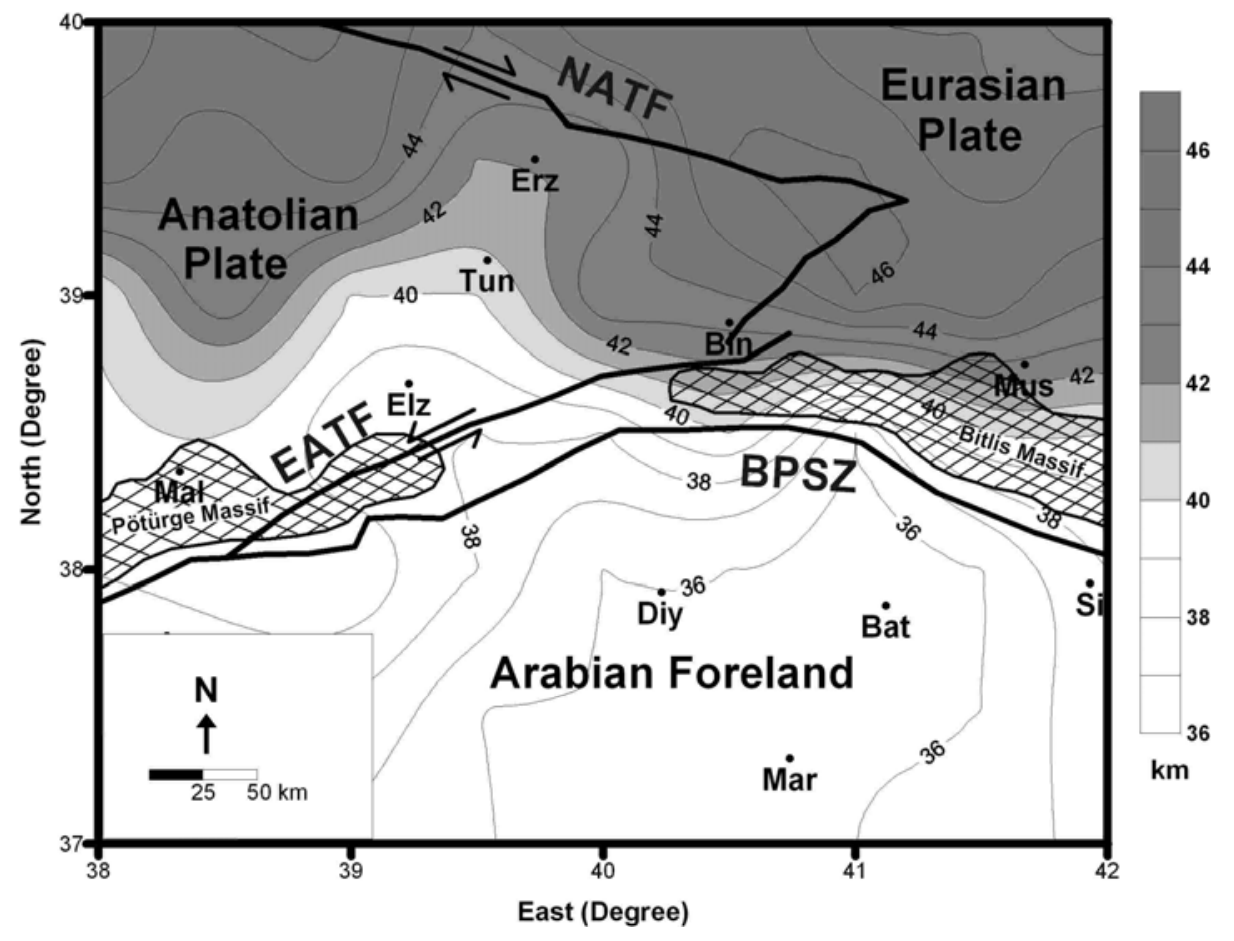

Fig. 2. Map showing the moho depth variation in eastern Turkey (from Elitok and Dolmaz, 2008). Contour interval: 1 km. NATF: North Anatolian Transform Fault; EATF: East Anatolian Transform Fault; BPSZ: Bitlis Pötürge Suture Zone; Mal: Malatya; Ady: Adıyaman; Elz: Elazığ; Tun: Tunceli; Erz: Erzincan; Bin: Bingöl; Diy: Diyarbakır; Mar: Mardin; Bat: Batman; Si: Siirt

\section{Curie point depth estimates}

The Curie Point Depth (CPD) is known as the depth at which the dominant magnetic mineral (ca $580{ }^{\circ} \mathrm{C}$ for magnetite) in the crust passes from a ferromagnetic state to a paramagnetic state under the effect of increasing temperature (Nagata, 1961). Beneath the Curie point depth the lithosphere shows virtually non-magnetic properties. Therefore, the basal depth of a magnetic source from aeromagnetic data is considered to be the CPD. Elitok and Dolmaz (2008) implied that the CPD is in close relationship with the crustal thickness, crust-hot asthenospheric mantle interactions, magmatic events, thermal structure of the crust and hence brittle upper crust-ductile lower crust transition zone. In capturing the estimates of the bottom of the deepest magnetic layer (Elitok and Dolmaz, 2008), the centroid method (Bhattacharyya and Leu, 1977; Okubo et al., 1985; Tanaka et al., 1999) was used. Moreover, the method of Okubo et al. (1985) has an advantage since large grid sizes of data are not necessary, whereas other studies require large grid sizes. The CPD may reflect the broad average temperature and regional crustal thermal structure (Tanaka and Ishikawa, 2005). It is important that the relative relations of estimated depths in a region are important rather than their numerical values. 
Elitok and Dolmaz (2008) performed two dimensional spectral analyses using divided subregions of size $90 \times 90 \mathrm{~km}$ overlapped $50 \%$ with the adjacent subregion. The average depth to the bottom of the deepest magnetic layer, the CPD $\left(z_{b}\right)$, is derived for an interested subregion by means of the Equation $z_{b}=2 z_{0}-z_{t}$. The top of the magnetic sources was found to be ca $2.31 \mathrm{~km}$ b.s.l. for the $90 \times 90 \mathrm{~km}$ subregions. On the other hand, the CPD vary between 11.05 and $23.57 \mathrm{~km}$ b.s.l. Figure 3 shows the CPD map of the study area (Elitok and Dolmaz, 2008) which is constructed from the CPD estimates by using the standard gridding routine. Three cross sections (Profiles 1,2 and 3) are produced from the CPD to show variation in depth of the $580{ }^{\circ} \mathrm{C}$ isotherm across the region and to compare the thermal structure of the crust with the topography and geological data of the region. Figures $6 a, 6 b$, and $6 \mathrm{c}$ show cross-sections including the topography, CPD and moho dephts.

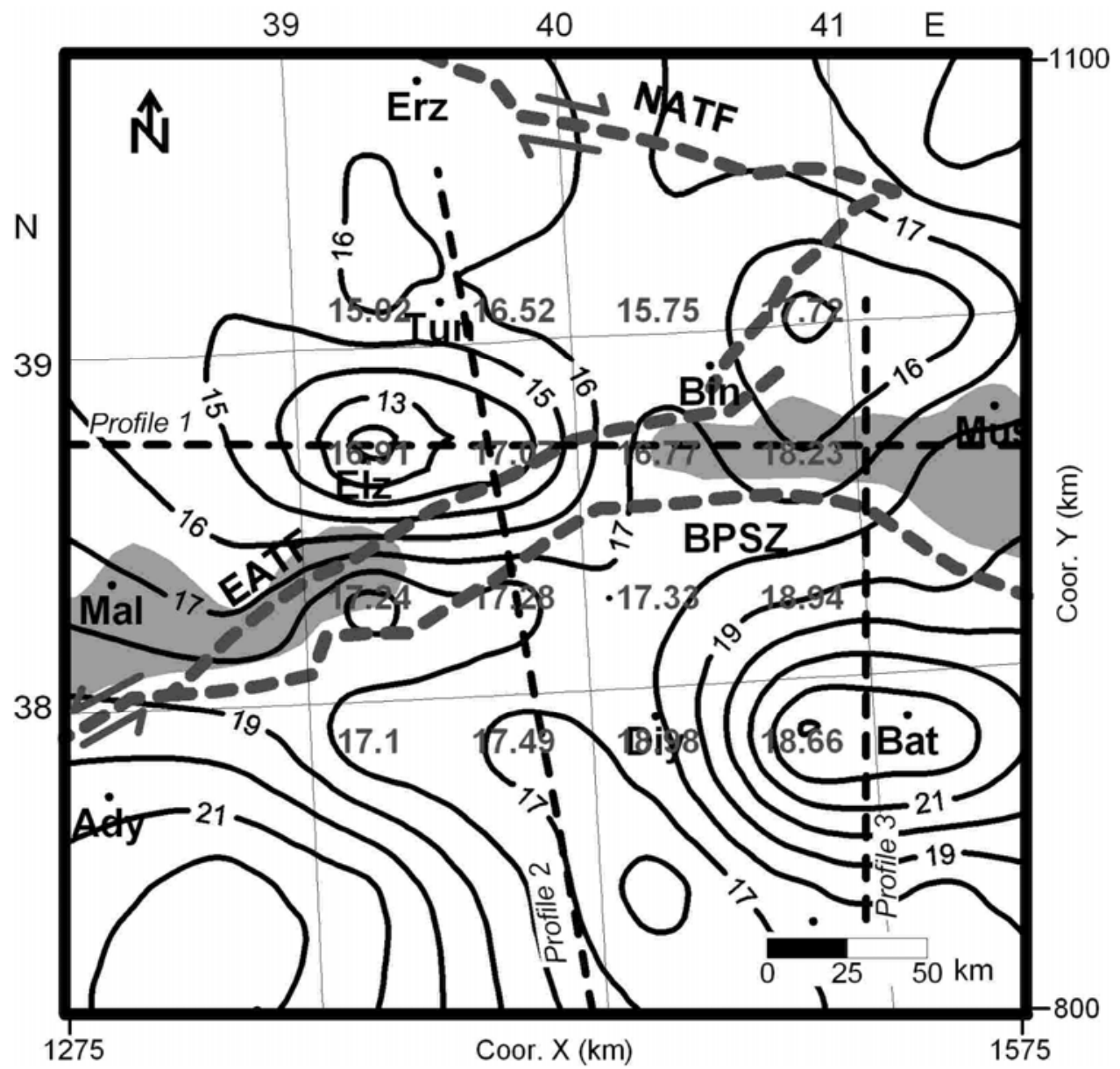

Fig. 3. The CPD map of the study area (from Elitok and Dolmaz, 2008). The CPD contours are drawn at $2 \mathrm{~km}$ intervals. Dashed lines indicate locations of the cross-sections used in Figure 4. City and major tectonic features names are same with Figure 2 


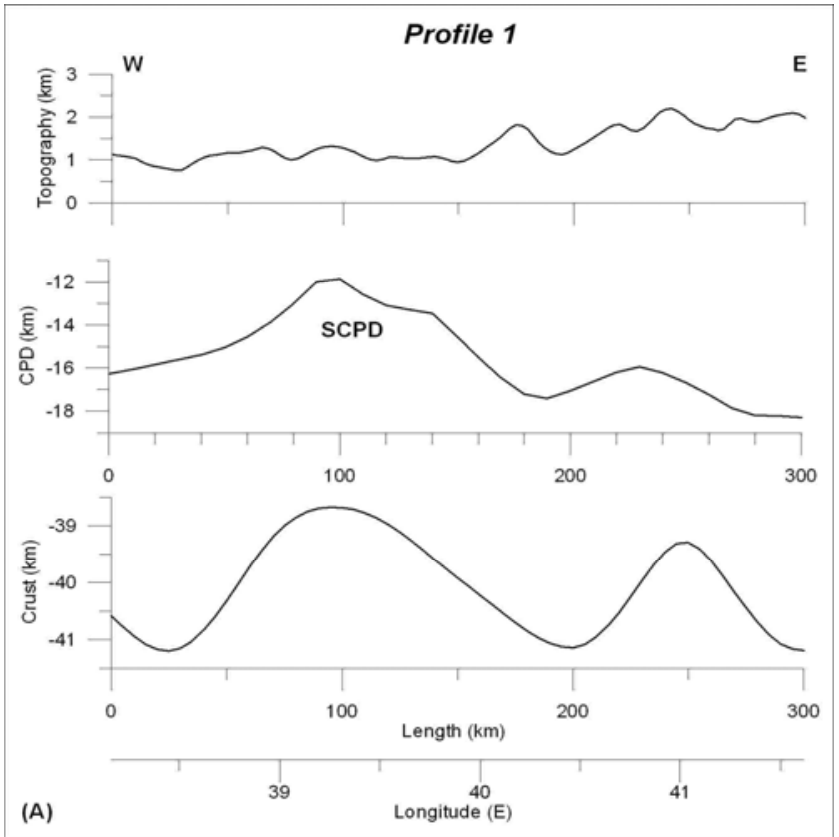

a)

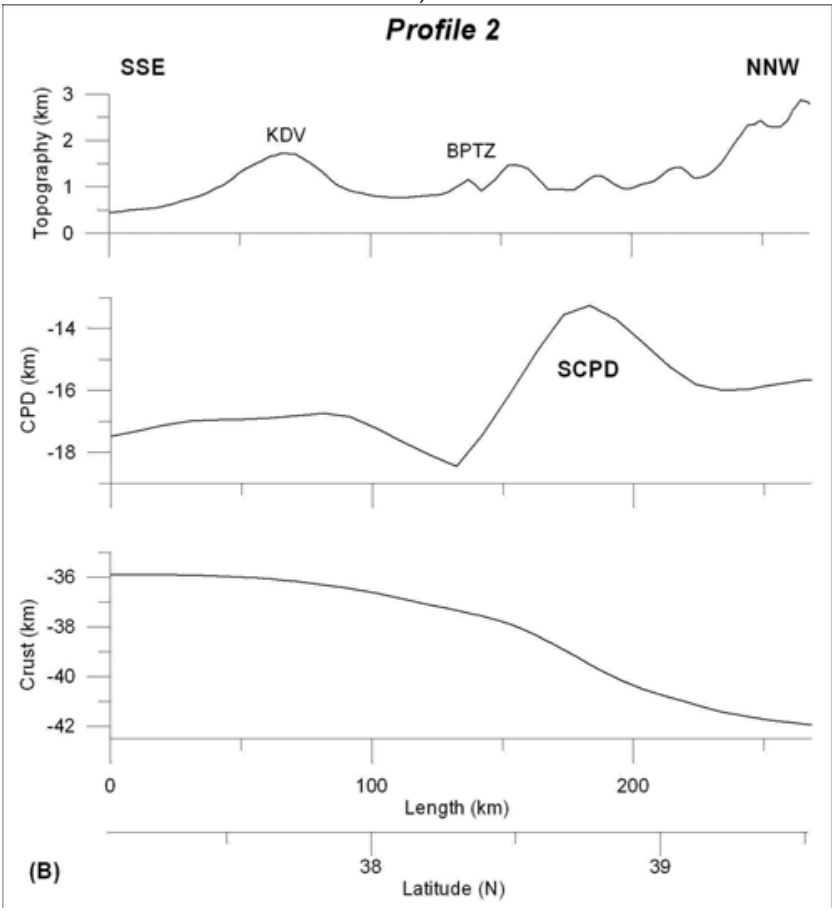

b) 


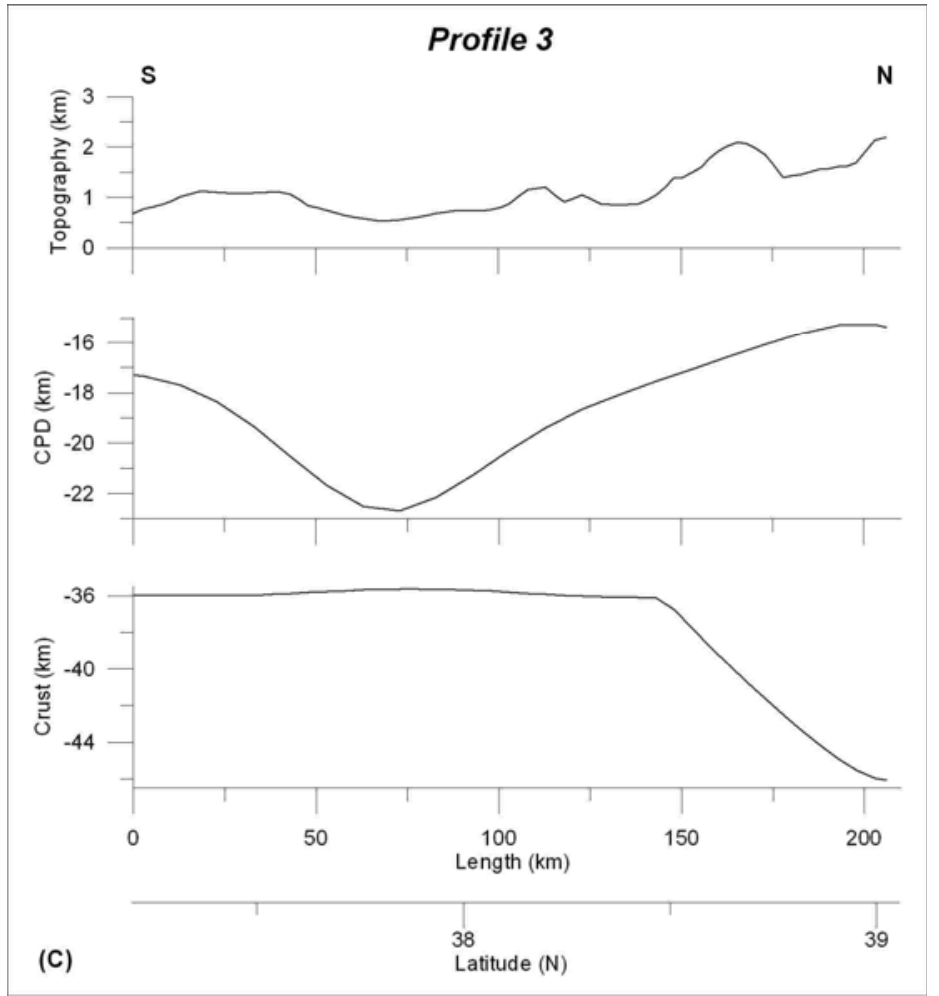

c)

Fig. 4. The cross-sections taken along the profiles in Figure 3 (from Elitok and Dolmaz, 2008), including topography, Curie isotherm depth (CPD), and moho depth (crust) a) Profile 1, b) Profile 2, and c) Profile 3. SCPD, shallow CPD; KDV, Karacadağ volcano, BPTZ: BitlisPötürge Thrust Zone. Length of profile is in $\mathrm{km}$ and also in degree sheet format

Profile 1: Profile 1 involves the E-W directed cross-sections with $300 \mathrm{~km}$ between latitudes 380-39o N (Figure 4a). The cross-section indicating CPD clearly illustrates the shallow Curie Point Depth (SCPD) between longitudes $39^{\circ}$ and $40^{\circ} \mathrm{E}$. This area is characterized by thinner crust of ca 38-39 km and very low Pn velocity zone $(<7.8 \mathrm{~km} / \mathrm{s}$; Figure 2a from Al-Lazki et al., 2003), corresponding to the metamorphic gap between the Bitlis Massif and the Pötürge Massif. The Curie point depth estimates in between 200 and $300 \mathrm{kms}$ of the profile tend to get shallow reaching a depth of ca $16 \mathrm{~km}$. This area with a $2200 \mathrm{~m}$ topographic height is represented by $39.5 \mathrm{~km}$ crust and low Pn velocities $(<8 \mathrm{~km} / \mathrm{s}$; Figure $2 \mathrm{a}$ from Al-Lazki et al., 2003).

Profile 2: Profile 2 indicates the NNW-SSE directed cross-sections with $270 \mathrm{~km}$ between longitudes 390-40 E (Figure 4b). The cross-section displays a shallow CPD (SCPD) in between 170-220 kms of the profile which corresponds to the location of shallow CPD of Profile 1. The Curie point depth estimates in the Karacadağ volcanic area (KDV) in between 30 and $80 \mathrm{kms}$ of the profile are characterized by ca $17 \mathrm{~km}$ deep. The Karacadağ volcanic area in the Arabian Foreland has an average crustal thickness of $36 \mathrm{~km}$ and low Pn velocity 
values (ca $8.0 \mathrm{~km} / \mathrm{s}$ ). In between latitudes of $38^{\circ}$ and $38.5^{\circ} \mathrm{N}$ on the profile, moderate deep $\mathrm{CPD}$ reaching a maximum depth of ca $18.5 \mathrm{~km}$ is located under the BPTZ, forming a plateau at a height of $1.65 \mathrm{~km}$ rugged topography. The negative spike on the CPD is consistent with the suture.

Profile 3: Profile 3 involves the N-S directed cross-sections with $206 \mathrm{~km}$ long around the longitude of $41^{\circ} \mathrm{E}$ (Figure $4 \mathrm{c}$ ). The cross-section generally shows the deep Curie point depth estimates reaching to a maximum depth of ca $22.5 \mathrm{~km}$. When compared the Profile 2 with the Profile 3, it is seen that the CPD on the Profile 2 is shallower (ca $17 \mathrm{~km}$ ) than the Profile 3 (ca $22.5 \mathrm{~km}$ ) in the south of the suture zone (in the Arabian Foreland) between the latitudes of $37.5^{\circ}-38^{\circ}$, suggesting most probably variations in the thickness of mantle lithosphere beneath the Arabian Foreland. High Al-Lazki et al. (2003) interpreted that Pn velocities beneath the Arabian Foreland sharply stop along the Bitlis Suture Zone.

\section{Conclusions}

There is a general consensus that the Neotectonic evolution of Turkey has been dominated by the collision of the African and Arabian plates with the Eurasian plate along the Hellenic arc to the west and the Bitlis-Zagros suture zone to the east (Wilson and Bianchini, 1999 and references therein). The EACP bounded by the PB in the north and the arc-shaped BPSZ in the south consists mainly of remnants of Tethyan oceanic lithosphere and Gondwana-derived continental blocks or microplates. This contractional province is still being squezzed between the Arabian and Eurasian plates, and experienced a compressional-extensional tectonic regime in connection with westward extrusion of the Anatolian plate. The eastern Anatolian contractional zone is dissected into three main lithospheric portions (EAHP, the Anatolian block, and the Arabian Foreland) by the major tectonic structures (BPSZ, NATFZ and EATFZ). Translation of the collision-related compressional stresses to the north (the Anatolian region) and to the south (the Arabian Foreland), mantle flow-driven extrusion tectonics and hot asthenospheric-lithospheric mantle interactions have been played a key role on the lithospheric evolution of the collisional zone. The present-day crust in the area between easternmost part of the Anatolian plate and the Arabian Foreland gets thinner from the NATFZ in the north (ca 43-44 km) to the Arabian Foreland in the south (ca $36-37 \mathrm{~km}$ ) through the metamorphic gap between the Bitlis and Pötürge massifs. This thinner crustal area is characterized by shallow CPD (12-16 km), very low Pn velocities $(<7.8 \mathrm{~km} / \mathrm{s})$ and high $\mathrm{Sn}$ attenuation which indicate partially molten to eroded mantle lid or occurrence of asthenospheric mantle beneath the crust. Northernmost margin of the Arabian Foreland in the south of the Bitlis-Pötürge metamorphic gap area is represented by moderate CPD $(16-18 \mathrm{~km})$ relative to its eastern and western sides, and low Pn velocities $(8 \mathrm{~km} / \mathrm{s})$. Elitok and Dolmaz (2008) infer from the geophysical data that the lithospheric mantle gets thinner towards the Bitlis-Pötürge metamorphic gap area in the northern margin of the Arabian Foreland which has been most probably caused by mechanical removal of the lithospheric mantle during mantle invasion to the north following the slab breakoff beneath the BPSZ. Mantle flow-driven rapid extrusion and counterclockwise rotation of the Anatolian plate gave rise to stretching and hence crustal thinning in the area between the easternmost part of the Anatolian plate and the Arabian Foreland which is currently dominated by wrench-tectonics (Figure 5). 

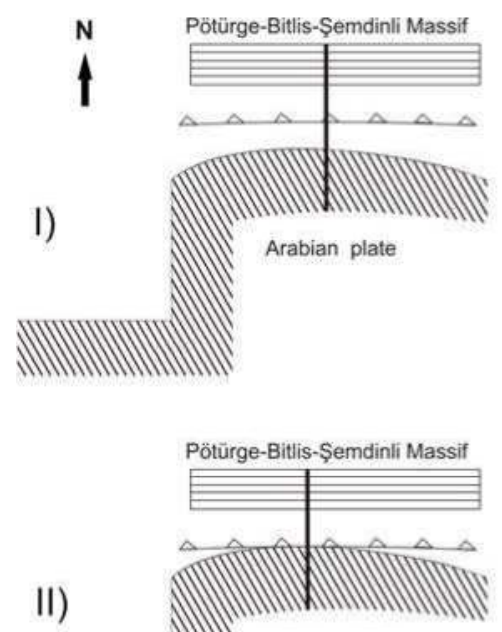

Arabian plate

III)

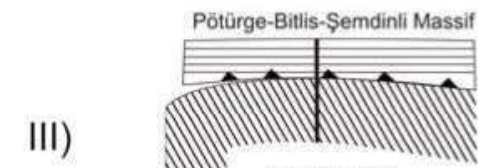

Arabian plate

IV)

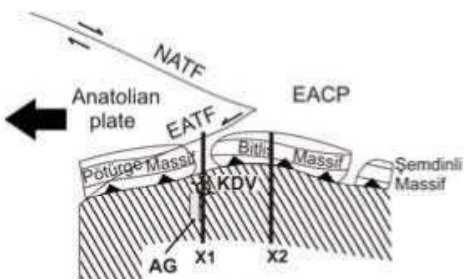

Arabian plate

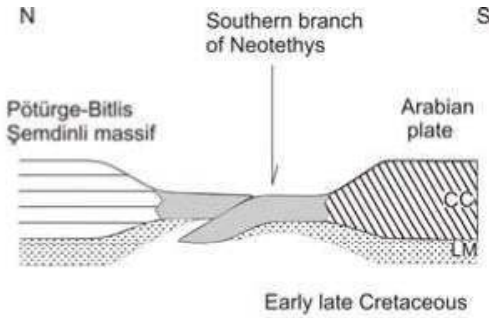

N

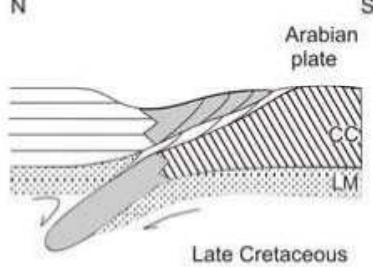

$\mathrm{N}$

S

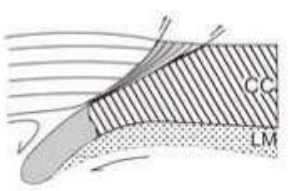

Late Cretaceous to Middle Miocene

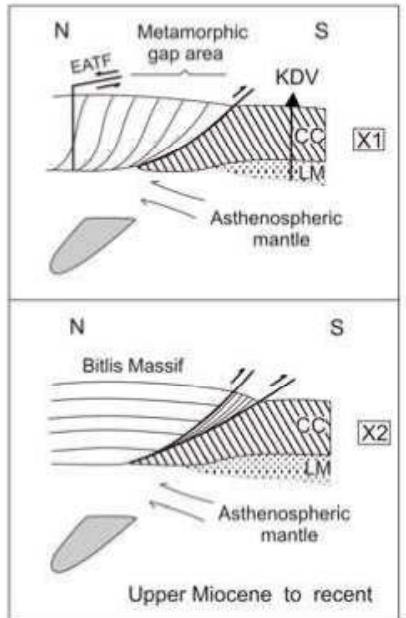

Fig. 5. Schematic tectonic model with cross-sections indicating Arabia-Eurasia collision and lithospheric evolution from late Cretaceous to recent (from Elitok and Dolmaz, 2008). (I) The northerly motion of Africa during Late Cretaceous resulted in a rapid convergence between Eurasia and Africa, and hence initiation of intraoceanic subduction zones in the Neotethys 
(Dilek and Moores, 1990; Dilek and Whitney, 2000 and references therein). (II) The continued convergence of the Africa-Arabia plate resulted in the emplacement of southern Neotethyan oceanic lithosphere on the Arabian platform during the Late Cretaceous (Dilek and Moores, 1990; Yilmaz et al., 1993). (III) During the initial continental collision, the northern margin of the Arabian plate subducted following the subducting oceanic lithosphere into the trench due to slab pull effect. (IV) The nappe stacks together with the accreted Gondwana-derived continental blocks were emplaced on the Arabian platform mainly in three phases (late Cretaceous, late-early Middle Eocene, Early Middle Miocene; Yilmaz et al., 1993; Bozkurt, 2001). The subducting oceanic lithosphere generated a large downward force and hence the oceanic lithosphere commenced to detach from the Arabian continental plate as proposed by Şengör et al. (2003), Keskin (2003 and 2007), Lei and Zhao (2007). The slab detachment most likely began $11 \mathrm{Ma}$ ago and lasted untill $8 \mathrm{Ma}$ (Şengör et al., 2003). The two continental masses (Bitlis-Pötürge metamorphic block and Arabian plate) came in contact with each other in the Upper Miocene (Innocenti et al., 1982). Northward motion of the Arabian plate continued after the slab breakoff and hence caused the breaking apart of the the Bitlis-Pötürge metamorphic block (Innocenti et al., 1982 and references therein). (IV) Compressional-contractional tectonic regime replaced by the compressionalextensional tectonic regime as proposed by Koçyiğit et al. (2001) following the slab breakoff, which corresponds to commencement of the westward extrusion of Anatolian plate. AG: Akçakale graben, CC: continental crust, EACP: Eastern Anatolian Contractinal Province, NATF: North Anatolian Transform Fault, EATF: East Anatolian Transform Fault, KDV: Karacadağ volcano, LM: lithospheric mantle.

\section{References}

Al-Lazki, A., Sandvol, E., Seber, D., Türkelli, N., Mohamad, R., Barazangi, M., 2003. Tomographic Pn velocity and anisotropy structure beneath the Anatolian plateau (eastern Turkey) and the surrounding regions. Geophysical Research Letters 30, 8043, doi:10.1020/2003GL018912.

Allen, M., Jackson, J., Walker, R., 2004. Late Cenozoic reorganization of the Arabia-Eurasia collision and the comparison of short-therm and long-therm deformation rates. Tectonics 23, TC2008, doi:10.1029/2003TC001530.

Barazangi, M., Sandvol, E., Seber, D., 2006. Structure and tectonic evolution of the Anatolian plateau in eastern Turkey. In: Dilek, Y., and Pavlides, S. (Eds.), Post-Collisional tectonics and magmatism in the eastern Mediterranean region and Asia. Geological Society of America Special Paper 409, 463-474.

Bhattacharyya, B. K., Leu, L. K., 1977. Spectral analysis of gravity and magnetic anomalies due to rectangular prismatic bodies. Geophysics 41, 41-50.

Bozkurt, E., 2001. Neotectonics of Turkey-a synthesis. Geodinamica Acta 14, 3-30.

Büyüksaraç, A., 2007. Investigation into the regional wrench tectonics of inner East Anatolia (Turkey) using potential field data. Physics of the Earth and Planetary Interiors 160, 8695.

Çoban, H., 2007. Basalt magma genesis and fractionation in collision- and extension-related provinces: a comparison between eastern, central and western Anatolia. EarthScience Reviews 80, 219-238.

Dewey, J.F., Hempton, M.R., Kidd, W.S.F., Şaroğlu, F., Şengör, A.M.C., 1986. Shortening of continental lithosphere: the neotectonics of Eastern Anatolia-a young collision 
zone. In: Coward, M.P. and Ries, A.C (Eds.), Collision Tectonics. Geological Society, London, Special Publications 19, 1-36.

Dhont, D., Chorowicz, J., Luxey, P., 2006. Anatolian escape tectonics driven by Eocene crustal thickening and Neogene-Quaternary extensional collapse in the eastern Mediterranean region. In: Dilek, Y. and Pavlides, S. (Eds.), Post-Collisional tectonics and magmatism in the eastern Mediterranean region and Asia. Geological Society of America Special Paper 409, 441-462.

Dilek Y., Moores, E.M., 1990. Regional tectonics of the eastern Mediterranean ophiolites. In: Malpas. J., Moores, E.M., Panayiotou, A., Xenophontos C. (Eds.), Ophiolites, Oceanic Crustal Analogues, Proceedings of the Symposium "Troodos 1987", Geological Survey Department, Nicosia, Cyprus, 295-309.

Dilek, Y., Whitney, D.L., 2000. Cenozoic crustal evolution in Central Anatolia: extension, magmatism and landscape development. In: Panayides, I., Xenophontos, C., Malpas, J. (Eds.), Proceedings of the Third International Conference on the Geology of the Eastern Mediterranean, September 1998, Nicosia, Cyprus, 183-192.

Elitok, Ö., Dolmaz, M.N., 2008. Mantle flow-induced crustal thinning in the area between the easternmost part of the Anatolian plate and the Arabian Foreland (E Turkey) deduced from the geological and geophysical data. Gondwana Research 13, 3, 302318, doi: 10.1016/j.gr.2007.08.007.

Faccenna, C., Bellier, O., Martinod, J., Piromallo, C., Regard, V., 2006. Slab detachment beneath eastern Anatolia: A possible cause for the formation of the North Anatolian fault. Earth and Planetary Science Letters 242, 85-97.

Gautier, P., Brun, J.-P., Moriceau, R., Sokoutis, D., Martinod, J., Jolivet, L., 1999. Timing, kinematics and cause of Aegean extension: a scenario based on a comparsion with simple analogue experiments. Tectonophysics 315, 31-72.

Gök, R., Sandvol, E., Türkelli, N., Seber, D., Barazangi, M., 2003. Sn attenuation in the Anatolian and Iranian plateau and surrounding regions. Geophysical Research Letters 30, 8042, doi:10.1029/2003GL018912.

Gök, R., Pasyanos, M., Zor, E., 2007. Lithospheric structure of the continent-continent collision zone: eastern Turkey. Geophysical Journal International 169, 1079-1088.

Gürer, Ö.F., Gürer, A., 1999. Development of evaporites and the counterclockwise rotation of Anatolia, Turkey. International Geology Review 41, 607-622.

Hall, R., 1976. Ophiolite emplacement and the evolution of the Taurus suture zone, southeastern Turkey. Geological Society of America Bulletin 87, 1078-1088.

Hubert-Ferrari, A., King, G., Manighetti, I., Armijo, R., Meyer, B., Tapponnier, P., 2003. Long-term elasticity in the continental lithosphere; modelling the Aden Ridge propagation and the Anatolian extrusion process. Geophysical Journal International 153, 111-132.

Innocenti, F., Mazzuoli, R., Pasquare, G., Radicati Di Brozolo, F., Villari, L., 1982. Tertiary and Quaternary volcanism of the Erzurum-Kars area (eastern Turkey): Geochronological data and geodynamic evolution. Journal of Volcanology and Geothermal Research 13, 223-240.

Keskin, M., 2003. Magma generation by slab steepening and breakoff beneath a subductionaccretion complex: An alternative model for collision-related volcanism in Eastern Anatolia, Turkey. Geophysical Research Letters 30, 8046, doi:10.1029/2003GL018019. 
Keskin, M., 2007. Eastern Anatolia: A hot spot in a collision zone without a mantle plume. In: Foulger, G.R. and Jurdy D. (Eds.), The Origins of Melting Anomalies: Plumes, Plates, and Planetary Processes (P4 Book). Geological Society of America Special Paper 430, 693-722.

Keskin, M., Pearce, J.A., Kempton, P.D., Greenwood, P., 2006. Magma-crust interactions and magma plumbing in a postcollisional setting: Geochemical evidence from the Erzuru-Kars volcanic plateau, eastern Turkey. In: Dilek, Y. and Pavlides, S. (Eds.), Post-Collisional tectonics and magmatism in the eastern Mediterranean region and Asia. Geological Society of America Special Paper 409, 475-505.

Koçyiğit, A., Yılmaz, A., Adamia, A., Kuloshvili, S., 2001. Neotectonics of East Anatolian Plateau (Turkey) and Lesser Caucasus: implication for transition from thrusting to strike-slip faulting. Geodinamica Acta 14, 177-195.

Lei, J., Zhao, D., 2007. Teleseismic evidence for a break-off subducting slab under Eastern Turkey. Earth and Planetary Science Letters 257, 14-28.

Lyberis, N., Yürür, T., Chorowicz, J., Kasapoğlu, E., Gündoğdu, N., 1992. The East Anatolian Fault: an oblique collision belt. Tectonophysics 204, 1-15.

McClusky, S., Balassanian, S., Barka, A., Demir, C., Ergintav, S., Georgiev, I., Gurkan, O., Hamburger, M., Hurst, K., Kahle, H., Kastens, K., Kekelidze, G., Ring, R., Kotzev, V., Lenk, O., Mahmoud, S., Mishin, A., Nadariya, M., Ouzounis, A., Paradissis, D., Peter, Y., Prilepin, M., Reilinger, R., Sanli, I., Seeger, H., Tealeb, A., Toksöz, M.N., Veis, G., 2000. Global positioning system constraints on plate kinematics and dynamics in the eastern Mediterranean and Caucasus. Journal of Geophysical Research-Solid Earth 105, 5695-5719.

Nagata, T., 1961. Rock Magnetism, 350 pp., Maruzen, Tokyo.

Okubo, Y., Graf, J.R., Hansen, R.O., Ogawa, K., Tsu, H., 1985. Curie Point Depths of the Island of Kyushu and Surrounding Areas, Japan. Geophysics 53, 481-494.

Özçep, F., Orbay, N., 2000. Paleomagnetic studies on the Anatolian (Turkish) plate and geodynamic implications: a review. Terra Nostra 10, From Secular Variation to Paleomagnetism-Workshop, Potsdam, pp 93-94.

Pearce, J.A., Bender, J.F., De Long, S.E., Kidd, W.S.F., Low, P.J., Güner, Y., Şaroğlu, F., Yilmaz, Y., Moorbath, S., Mitchell, J.G., 1990. Genesis of collision volcanism in Eastern Anatolia, Turkey. Journal of Volcanology and Geothermal Research 44, 189-229.

Platzman, E.S., Tapirdamaz, C., Sanver, M., 1998. Neogene anticlockwise rotation of central Anatolia (Turkey): preliminary paleomagnetic and geochronological results. Tectonophysics 299, 175-189.

Reilinger, R.E., McClusky, S.C., Oral, M.B., King, W., Toksöz, M.N., Barka, A.A., Kınık, I., Lenk, O., Sanlı, I., 1997, Global Positioning System measurements of present-day crustal movements in the Arabian-Africa-Eurasia plate collision zone. Journal of Geophysical Research-Solid Earth 102, 9983-9999.

Sandvol, E., Türkelli, N., Barazangi, M., 2003. The Eastern Turkey Seismic Experiment: The study of a young continent-continent collision. Geophysical Research Letters 30, 8038, doi:10.1029/2003GL018912.

Seyitoğlu, G., Scott, B.C., 1996. The cause of N-S extensional tectonics in western Turkey: tectonic escape vs back-arc spreading vs orogenic collapse. Journal of Geodynamics 22, 145-153.

Şengör, A.M.C., 1979. The North Anatolian transform fault: its age, offset and tectonic significance. Journal of the Geological Society 136, 269-282. 
Şengör, A.M.C., Görür, N., Şaroğlu, F., 1985. Strike-slip faulting and related basin formation in zones of tectonic escape: Turkey as a case study. In: Biddle, K.T. and ChristieBlick, N. (Eds.), Strike-slip Deformation, Basin Formation and Sedimentation. Society of Economic Mineralogist and Paleontologists Special Publication 37, 227-264.

Şengör, A.M.C., Özeren, S., Genç, T., Zor, E., 2003. East Anatolian high plateau as a mantlesupported, North-south shortened domal structure. Geophysical Research Letters 30, 8045, doi:10.1029/2003GL017858.

Şengör, A.M.C., Y1lmaz, Y., 1981. Tethyan evolution of Turkey: a plate tectonic approach. Tectonophysics 75, 181-241.

Tanaka, A., Okubo, Y., Matsubayashi, O., 1999. Curie Point Depth Based on Spectrum Analysis of the Magnetic Anomaly Data in East and Southeast Asia. Tectonophysics 306, 461-470.

Tanaka, A., Ishikawa, Y., 2005. Crustal thermal regime inferred from magnetic anomaly data and its relationship to seismogenic layer thickness: The Japanese islands case study. Physics of the Earth and Planetary Interiors 152, 257-266.

Tatar, O., Piper, J.D.A., Gürsoy, H., Temiz, H., 1996. Regional significance of Neotectonic counterclockwise rotation in Central Turkey. International Geology Review 38, 692700 .

Wilson, M., Bianchini, G., 1999. Tertiary-Quaternary magmatism within the Mediterranean and surrounding regions. In: Durand, B., Jolivet, L., Horvath, F., Seranne, M. (Eds.), The Mediterranean Basins: Tertiary Extension within the Alpine Orogen. Geological Society, London, Special Publications 156, 141-168.

Yazgan, E., 1981. Doğu Toroslarda etkin bir paleo-kıta kenarı etüdü (Üst Kretase-Orta Eosen) Malatya-Elazı̆̆g, Doğu Anadolu. Journal of the Earth Sciences Application and Research Centre of Hacettepe University 7, 83-104.

Yilmaz, Y., 1993. New evidence and model on the evolution of the southeast Anatolian orogen. Geological Society of America Bulletin 105, 251-271.

Yılmaz, Y., Yiğitbaş, E., Genç, Ş.C., 1993. Ophiolitic and metamorphic assemblages of southeast Anatolia and their significance in the geological evolution of the orogenic belt. Tectonics 12, 1280-1297.

Yılmaz Y., Güner, Y., Şaroğlu, F., 1998. Geology of the Quaternary volcanic centers of the east Anatolia. Journal of Volcanology and Geothermal Research 85, 173-210.

Yılmaz, Y., Yıldırım, M., 1996. Geology and evaluation of the Nap Region (the Metamorphic Massif) of the southeast Anatolian orogenic belt. Turkish Journal of Earth Sciences 5, 21-38.

Yiğitbaş., E., Genç, Ş.C., Yılmaz, Y., 1993. Güneydoğu Anadolu orojenik kuşağında Maden Grubunun tektonik konumu ve jeolojik önemi. A. Suat Erk Sempozyumu Bildirileri, 25 Eylül, A.Ü. Fen Fakültesi Jeoloji Mühendisliği Bölümü, Ankara, 251-264 (in Turkish with English abstract).

Yiğitbaş, E., Yılmaz, Y., 1996. New evidence and solution to Maden Complex controversy of the southeast Anatolian orogen (Turkey). Geologische Rundschau 85, 250-263.

Zor, E., Gürbüz, C., Türkelli, N., Sandvol, E., Seber, D. and Barazangi, M., 2003. The crustal structure of the East Anatolian Plateau from receiver functions. Geophysical Research Letters 30, 8044, doi:10.1029/2003GL018192. 


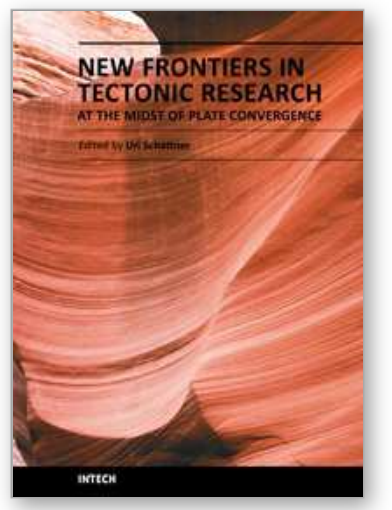

\section{New Frontiers in Tectonic Research - At the Midst of Plate Convergence}

Edited by Dr. Uri Schattner

ISBN 978-953-307-594-5

Hard cover, 352 pages

Publisher InTech

Published online 09, August, 2011

Published in print edition August, 2011

Ocean closure involves a variety of converging tectonic processes that reshape shrinking basins, their adjacent margins and the entire earth underneath. Following continental breakup, margin formation and sediment accumulation, tectonics normally relaxes and the margins become passive for millions of years. However, when final convergence is at the gate, the passive days of any ocean and its margins are over or soon will be. The fate of the Mediterranean and Persian Gulf is seemingly known beforehand, as they are nestled in the midst of Africa-Arabia plate convergence with Eurasia. Over millions of years through the Cenozoic era they progressively shriveled, leaving only a glimpse of the Tethys Ocean. Eventually, the basins will adhere to the Alpine-Himalaya orogen and dissipate. This book focuses on a unique stage in the ocean closure process, when significant convergence already induced major deformations, yet the inter-plate basins and margins still record the geological history.

\section{How to reference}

In order to correctly reference this scholarly work, feel free to copy and paste the following:

Omer Elitok and M. Nuri Dolmaz (2011). Tectonic Escape Mechanism in the Crustal Evolution of Eastern Anatolian Region (Turkey), New Frontiers in Tectonic Research - At the Midst of Plate Convergence, Dr. Uri Schattner (Ed.), ISBN: 978-953-307-594-5, InTech, Available from: http://www.intechopen.com/books/newfrontiers-in-tectonic-research-at-the-midst-of-plate-convergence/tectonic-escape-mechanism-in-the-crustalevolution-of-eastern-anatolian-region-turkey-

\section{INTECH}

open science | open minds

\section{InTech Europe}

University Campus STeP Ri

Slavka Krautzeka 83/A

51000 Rijeka, Croatia

Phone: +385 (51) 770447

Fax: +385 (51) 686166

www.intechopen.com

\section{InTech China}

Unit 405, Office Block, Hotel Equatorial Shanghai

No.65, Yan An Road (West), Shanghai, 200040, China

中国上海市延安西路 65 号上海国际贵都大饭店办公楼 405 单元

Phone: +86-21-62489820

Fax: $+86-21-62489821$ 
(C) 2011 The Author(s). Licensee IntechOpen. This chapter is distributed under the terms of the Creative Commons Attribution-NonCommercialShareAlike-3.0 License, which permits use, distribution and reproduction for non-commercial purposes, provided the original is properly cited and derivative works building on this content are distributed under the same license. 